\title{
永久磁石形リニア同期モータの静推力特性
}

\author{
正員水 野 勉 (アマダ) \\ 正員山田 一 (信州)
}

\section{Static Thrust Characteristics of Permanent Magnet Type Linear Synchronous Motor}

Tsutomu Mizuno, Member(Amada Co., Ltd.), Hajime Yamada, Member (Shinshu University)

This paper deals with the analyzing results of static thrust of a permanent magnet type linear synchronous motor (LSM) from both sides of theory and experiment. It is necessary to make clear how the width and taper length of the permanent magnet affect static thrust characteristics of a LSM, because it was not so definite.

In this paper, the following points are discussed:

(1) The theoretical expressions of the static thrust of the LSM were derived from the permeance analysis method and finite element method(FEM).

(2) The width and taper length of the permanent magent which give influence on harmonic components of static thrust were investigated through the FEM. The error of calculated value through the FEM is found within $10 \%$ of measured value of speed electromotive force and static thrust.

(3) The error through the permeance analysis method is found within $20 \%$ of measured value. The calcurated value in the permeance analysis method corresponded likely to the mean static thrust of measured value.

キーワード：リニアモータ, 永久磁石形リニア同期モータ, 静推力解析, パーミアンス法, 有限要素法, 静推力高調波成分, 磁石幅, 磁石テーパ長さ

\section{1.まえがき}

FA 機器の高速化に伴い, 高速・高精度位置決め性 能を有する永久磁石形りニア同期モー夕（Permanent Magnet Type Linear Synchronous Motor, 以 下LSM）が注目されている(1)。

LSM の FA 機器への応用として, 苅田ら ${ }^{(2)}$ 宮下 $ら^{(3)}$ の LSM の静推力特性に関する先駆的な研究がな されている。苅田らは，BLI 則を用いた永久磁石形 LSM の設計手法を示した。また宮下らは, LSM の 静推力特性について,パーミアンス法でLSM の歯形 状が静推力特性に及ぼす影響について検討している。

しかしながら，LSM の静推力の解析手法や磁石形 状などが静推力に与える影響については，LSM の設
計上, 更に検討が必要であると考えられる。

著者らは, 産業機械の高速・高精度化要求に対して, 永久磁石形 LSM のサーボ化を行い，その静推力特性 を検討してきだ(4)。

本論文は, 永久磁石形 LSM の静推力特性について 考察したものであり，以下の項目を明らかにしょうと するものである。

(1) パーミアンス法扔よび有限要素法（以下, FEM と略記) によって, 永久磁石形 LSM の静推力 の表現式を導出する。

（2） FEM を用いて，永久磁石形状が静推力の基 本波および高調波成分に与える影響について检討 する。

（3）上記検討結果に基づいて LSM の試作を行 
い, 觧推力の実測值と計算值を比較し，解析の妥当性 を碓認する。

\section{2. 永久磁石形 LSM の基本構造}

〈2・1〉永久磁石形LSM の構造図 1 は永久磁 石形 LSM の基本搆造を示したものである。一次僛は 可動子て，電磁銅板が積層された電機子鉄心に分布巻 された三相巻線が施されており，6極構造となってい る。二次側 (固定子) る面が $N, S$ 交互になるように永久磁石が配置され ている。

一次側と二次側間のギャップは, 直接軸受により, $0.7 \mathrm{~mm}$ に保たれている。フックとピニオンにより直 線／回転運動変掺をし，ピ二オンに取付けられた回転 形エンコーダを用いて位置を検出している。また，一

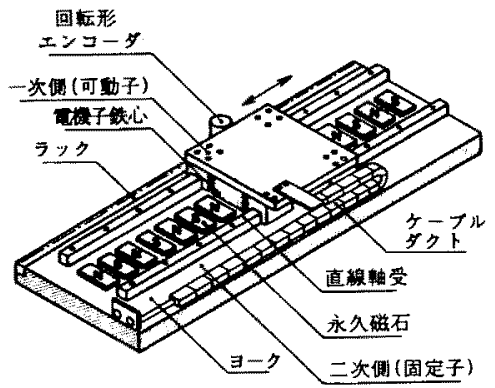

图 1 永久磁石形 LSM 9 基本構造

Fig. 1. Basic structure of PM type LSM.

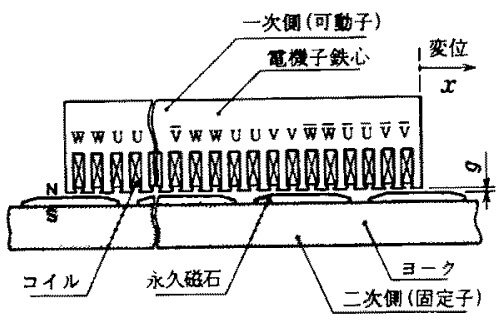

(a)モザル全体图

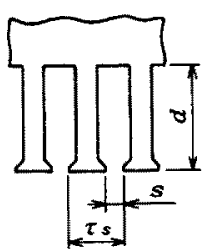

(b) 一次側の電古法

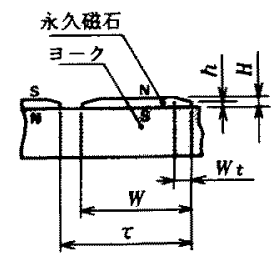

(c) 永久酳石法
図 2 永久磁石形 LSM $\sigma$ 解析乇デル

Fig. 2. Analysis model of the PM type LSM.
次側およびェンコーダへの給電は，ヶーブルダクト内 のケープルで行っている。

〈2・2〉解析モデル 永久磁石形 LSMをサーボ モータとして応用するためには，大きな推力で，かつ 推力リプルが小さいことが要求される。そこて，永久 磁石の形状寸法が，静推力の基本波扝上げ高調波成分 に与える影響について検討する。

図 2 は永久磁石形 LSM の解析モデルを示したもの である。(a)図は解析モデル全体図，(b)図は一次側 の歯寸法，(c)図は永久磁石寸法である。表1に永久 磁石形LSM の解析モデルの諸元を示す。同表に示す ように、ポールピッチ $t=40 \mathrm{~mm}$ おびスロットピ ッチ $\tau_{s}=6.667 \mathrm{~mm}$ などの一次側の絭寸法は一定のま まで, 磁石幅 $W=28 \sim 40 \mathrm{~mm}(W / \tau=0.7 \sim 1.0)$, 磁 石のテーパ長き $W_{t}=0 \sim 10 \mathrm{~mm}\left(W_{t} / W=0 \sim 0.3\right)$ の館 囲で変化させ，Wおよび $W_{t}$ が静推力の基本波およ ぜ高調波成分に与える影響について考察する。

〈2・3〉駆動回路の構成図 3 にLSM の駆動回 路の構成を示す。回転形エンコーダの位置信與から， 一次側の変位 $x$ に対応して変化する三相正弦波を茾 一ボアンブ内で作る。この三相正弦波と電流指令の大 きさ比例した三相正弦波電流 $I_{u}, I_{v}, I_{w} は$ ，各コ イルに供給され，それぞれ次式で与えられる。

$$
\begin{aligned}
& I_{u}=\sqrt{2} I \sin \left(\frac{\pi}{\tau} x\right) \quad(\mathrm{A}) \\
& I_{v}=\sqrt{2} I \sin \frac{\pi}{\tau}\left(x+\frac{2}{3} \tau\right) \\
& I_{w}=\sqrt{2} I \sin \frac{\pi}{\tau}\left(x-\frac{2}{3} \tau\right) \\
& こ こ に, I: \text { 䉓流 }(\mathrm{A})
\end{aligned}
$$

\begin{tabular}{|c|c|c|c|c|}
\hline 垻 & 回 & & 数 & 值 \\
\hline $\begin{array}{l}\text { - 次 賏 } \\
\text { (可针子) }\end{array}$ & 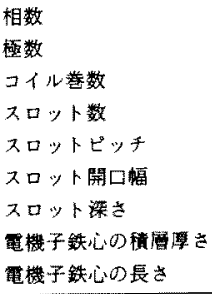 & $\begin{array}{l}m \\
P \\
N \\
N_{s} \\
\tau_{s} \\
s \\
d \\
L \\
l\end{array}$ & $\begin{array}{c}3 \\
6 \\
216 \\
36 \\
6.667 \\
2.2 \\
15 \\
68 \\
243\end{array}$ & $\begin{array}{l}\text { 䔩 } \\
\text { 極 } \\
\text { 回/相 } \\
\text { 艋 } \\
\mathrm{mm} \\
\mathrm{mm} \\
\mathrm{mm} \\
\mathrm{mm} \\
\mathrm{mm}\end{array}$ \\
\hline $\begin{array}{l}\text { 二 欢 賠 } \\
\text { (固定子) }\end{array}$ & 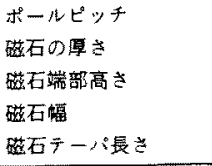 & $\begin{array}{l}\tau \\
H \\
h \\
W \\
W_{t}\end{array}$ & $\begin{array}{c}40 \\
3 \\
1.5 \\
28-40 \\
0-10\end{array}$ & $\begin{array}{l}\mathrm{mm} \\
\mathrm{mm} \\
\mathrm{mm} \\
\mathrm{mm} \\
\mathrm{mm}\end{array}$ \\
\hline \multicolumn{2}{|c|}{ ギャッブの長さ } & $g$ & 0.7 & $\mathrm{~mm}$ \\
\hline
\end{tabular}

表 1 永久磁石形LSMの解析モデルの諸元 Table 1. Parameters of the model. 


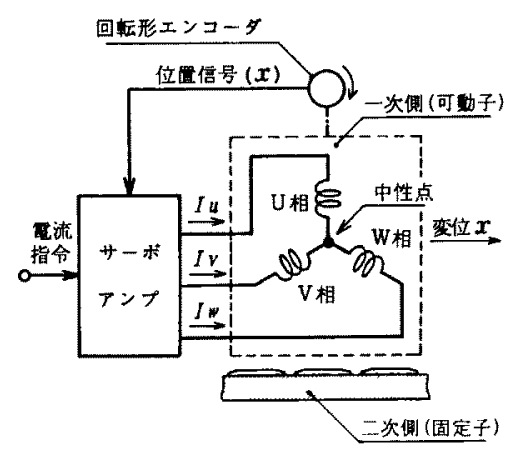

図 3 LSM の駆動回路の構成

Fig. 3. Constitution of a driving circuit for LSM.

本論文では，前式に示した三相正弦波電流を各コイ ルに供給した場合に発生する静推力を「静推力（三 相)」と呼び,一相のコイルの巻始めと中性点間に直 流電流を流した場合に発生する静推力を「静推力(一 相)」と呼ぶことにする。

\section{3. 静推力の表現式}

〈3・1〉 パーミアンス法による静推力の表現式 パーミアンス法による静推力の表現式の導出にあた り，以下の仮定を設ける。

（1）一次側端部からの漏れ磁束は無視する。

（2）ギャップに抢ける磁束は正弦波分布とする。

（3）電機子鉄心およびヨークの透磁率汁無限大 とし，この部分の磁気抵抗は考慮しない。

上記の仮定に基づき永久磁石形 LSM の磁気等価回 路は，永久磁石 1 極分索考慮して図 4の上うになる。 同図において， $F_{m}$ は永久磁石の起磁力, $R_{m}$ は永久 磁石の内部磁気抵抗， $R_{g}$ はギャップの磁気抵抗である。 図中記号を用いて永久磁石 1 極あたりの磁束 $\Phi_{m}$ は 下式で求められる。

$$
\Phi_{m}=F_{m} /\left(R_{m}+R_{g}\right) \quad(\mathrm{Wb})
$$

一次側可動子を一定速度 $d x / d t$ で移動させた場合

に，U相コイルに発生する速度起電力 $V_{u}$ (相電压)

は, 次式で求められるる

$$
V_{u}=\left\{\frac{\pi K_{w} N \Phi_{m}}{\tau} \sin \left(\frac{\pi}{\tau} x\right)\right\} \frac{d x}{d t}
$$

$こ こ に ， K_{w}$ : 巻線係数, $N:$ 一相あたりの

コイル菅数

次に, $U$ 相のコイルに直流電流を流した場合の静 推力 (一相) $F_{u x}$ ，および三相正弦波電流〔( 1$) \sim(3)$ 式〕を流した場合の静推力（三相） $F_{x}$ は下式となる(5)。

$$
F_{u x}=-\frac{m \pi K_{w} \Phi_{m}}{3 \tau} N I_{0} \sin \left(\frac{\pi}{\tau} x\right) \quad(\mathrm{N}) \cdots(6)
$$

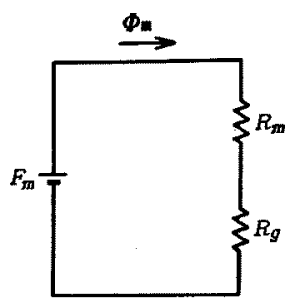

図 4 パーミアンス法によるLSMの磁気 等価回路

Fig. 4. Magnetic equivalent circuit of the LSM by permeance analysis method.

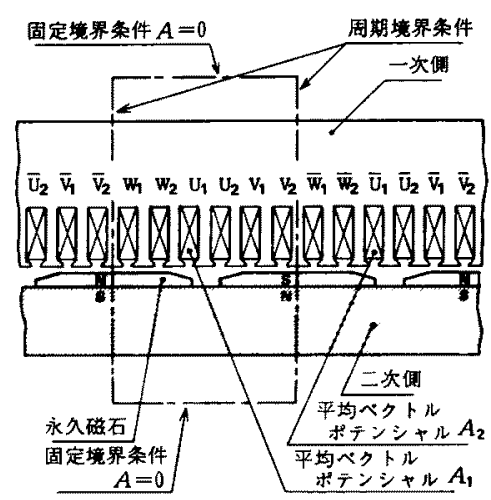

図 5 鎤交磁束を求めるための FEM の 計算モデル

Fig. 5. The model of calculation for interlinkage flux.

$$
F_{x}=-\frac{m \pi K_{w} \Phi_{m}}{\sqrt{2} \tau} N I \quad(\mathrm{~N})
$$

ここに， $m$ : 巻線の相数， $I_{0}$ : 直流電流 $(\mathrm{A})$

〈3・2〉有限要素法による静推力の表現式 有限 要素法による静推力の表現式は, 二次元非線形場の FEM (ベクトルポテンシャル法) を用いて導出する。 まず, コイルの鎮交磁束を求め，次に速度起電力，静 推力を以下のように求める。

（1）鎮交磁束 図 5 に鎖交磁束を求めるための FEM の計算モデルを示す。一次側と二次側の位置関 係が同図の場合を変位 $x=0$ としたとき, コイル $U_{1}$, $\bar{U}_{1}$ に鎖交する磁束 $\Phi$ は，次式で与えられる ${ }^{(6)}$ 。

$\Phi=\left(A_{1}-A_{2}\right) L \quad(\mathrm{~Wb})$

ここに, $A_{1}, A_{2}:$ コル $U_{1}, \bar{U}_{1}$ の平均べ

クトルポテンシャル $(\mathrm{Wb} / \mathrm{m}), L$ : 電機子

鉄心の積層厚さ（m)

一次側を移動させて各変位での鎖交磁束を求め,こ れをフーリ工級数展開し，各相の全鎖交磁束 $\Psi_{u}$, $\Psi_{v} ， \Psi_{w}$ として表すと下式のようになる。 


$$
\begin{aligned}
& \Psi_{u}=N \sum_{n=1}^{\infty} K_{w n} \Phi_{n} \cos \left(\frac{\pi}{\tau} n x\right) \\
& \Psi_{v}=N \sum_{n=1}^{\infty} K_{w n} \Phi_{n} \cos \frac{\pi}{\tau} n\left(x+\frac{2}{3} \tau\right) \\
& \Psi_{w}=N \sum_{n=1}^{\infty} K_{w n} \Phi_{n} \cos \frac{\pi}{\tau} n\left(x-\frac{2}{3} \tau\right)
\end{aligned}
$$

ここに, $K_{w n}$ : 第 $n$ 次高調波成分の巻線係

数， $\Phi_{n}$ : 鎖交磁束の第 $n$ 次成分 $(\mathrm{Wb})$

（2）速度起電力 本論文では後述するように, 鎖交磁束を用いて静推力の表現式を導出する。そこ で，鎖交磁束の解析精度を確認するために速度起電力 の表現式を導出しておく。

一次側可動子を一定速度で移動させた場合の各相の 速度起電力 $V_{u}, V_{v}, V_{w}$ (相電圧) は, $(9) \sim(11)$ 式を用いて次式となる。

$$
\begin{aligned}
& V_{u}=-d \Psi_{u} / d t \\
& =\left\{\frac{\pi}{\tau} N \sum_{n=1}^{\infty} n K_{w n} \Phi_{n} \sin \left(\frac{\pi}{\tau} n x\right)\right\} \frac{d x}{d t} \\
& V_{w}=\left\{\frac{\pi}{\tau} N \sum_{n=1}^{\infty} n K_{w n} \Phi_{n} \sin \frac{\pi}{\tau} n\left(x-\frac{2}{3} \tau\right)\right\} \frac{d x}{d t}
\end{aligned}
$$

（3）静推力 $U$ 相の静推力（一相） $F_{u x}$ は, $U$ 相に電流を流すことによって発生する推力 $F_{u}$ (以 下, 発生推力と呼ぶ）とディテント力 $F_{d}$ の和として 表され，次式が成立する。

$$
F_{u x}=F_{u}+F_{d} \quad(\mathrm{~N})
$$

発生推力 $F_{u}$ は, 次式で求められる。

$$
\begin{aligned}
F_{u} & =d W_{m u} / d x \\
& =-\frac{\pi}{\tau} N I_{0} \sum_{n=1}^{\infty} n K_{w n} \Phi_{n} \sin \left(\frac{\pi}{\tau} n x\right)
\end{aligned}
$$

ここに, $W_{m u}$ : 磁気随伴エネルギー $(\mathrm{J})$

$\left(=\Psi_{u} \times I_{0}\right)$

ディテントカ $F_{d}$ は, 図 6 に示すように可動子全体 を含む領域で，FEM を用いて永久磁石によるギャッ プの磁束分布を求め, 次にマクスウェルの応力法で計 算した。同図中に, 解析に用いた境界条件と, 解析で 得られた磁束分布を図示した。

一次側可動子と二次側固定子の相対位置を変化させ て求めたディテントカを, フーリエ級数展開し下式で

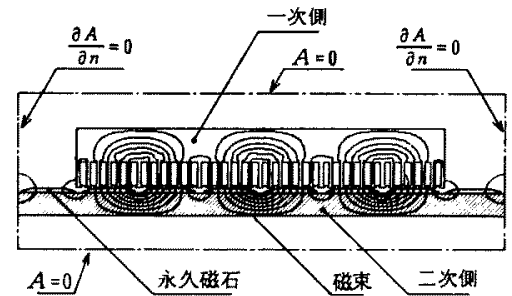

図 6 ディテント力を求めるための FEM の 計算モデルと磁束分布

Fig. 6. The model of calculation for detent thrust and flow of flux.

表す。

$$
\begin{aligned}
& F_{d}=\sum_{n=1}^{\infty} F_{d n} \sin \left(\frac{\pi}{\tau} n x\right)(\mathrm{N}) \cdots \cdots \cdots \cdots(17) \\
& \text { ここに, } F_{d n}: \text { ディテントカの第 } n \text { 次成分 }
\end{aligned}
$$

従って，(15)式の静推力（一相） $F_{u x}$ は，(16)式と (17)式から以下のようになる。

$$
\begin{aligned}
F_{u x}= & -\frac{\pi}{\tau} N I_{0} \sum_{n=1}^{\infty} n K_{w n} \Phi_{n} \sin \left(\frac{\pi}{\tau} n x\right) \\
& +\sum_{n=1}^{\infty} F_{d n} \sin \left(\frac{\pi}{\tau} n x\right) \text { (N) } \cdots \cdots
\end{aligned}
$$

同様にして, $V, W$ 相の静推力 (一相) $F_{v x}, F_{w x}$ は次式となる。

$$
\begin{aligned}
F_{v x}= & -\frac{\pi}{\tau} N I_{0} \sum_{n=1}^{\infty} n K_{w n} \Phi_{n} \sin \frac{\pi}{\tau} n\left(x+\frac{2}{3} \tau\right) \\
& +\sum_{n=1}^{\infty} F_{d n} \sin \left(\frac{\pi}{\tau} n x\right) \quad(\mathrm{N}) \cdots \cdots \cdots(19) \\
F_{w x}= & -\frac{\pi}{\tau} N I_{0} \sum_{n=1}^{\infty} n K_{w n} \Phi_{n} \sin \frac{\pi}{\tau} n\left(x-\frac{2}{3} \tau\right) \\
& +\sum_{n=1}^{\infty} F_{d n} \sin \left(\frac{\pi}{\tau} n x\right) \quad(\mathrm{N}) \cdots \cdots \cdots(20)
\end{aligned}
$$

次に，(1)〜（3)式に示した三相正弦波電流を各相 に流した場合の静推力 (三相) は, 各相の発生推力とデ イテントカの和として以下のようになる。

$$
\begin{aligned}
F_{x}= & -\frac{\sqrt{2} \pi}{\tau} N I\left\{\sin \left(\frac{\pi}{\tau} x\right) \times \sum_{n=1}^{\infty} n K_{w n} \Phi_{n}\right. \\
& \times \sin \left(\frac{\pi}{\tau} n x\right)+\sin \frac{\pi}{\tau}\left(x+\frac{2}{3} \tau\right) \\
& \times \sum_{n=1}^{\infty} n K_{w n} \Phi_{n} \sin \frac{\pi}{\tau} n\left(x+\frac{2}{3} \tau\right) \\
& +\sin \frac{\pi}{\tau}\left(x-\frac{2}{3} \tau\right) \\
& \left.\times \sum_{n=1}^{\infty} n K_{w n} \Phi_{n} \sin \frac{\pi}{\tau} n\left(x-\frac{2}{3} \tau\right)\right\} \\
& +\sum_{n=1}^{\infty} F_{d n} \sin \left(\frac{\pi}{\tau} n x\right) \quad \text { (N) } \cdots \cdots \cdots . . .
\end{aligned}
$$

永久磁石形 LSM をサーボモータとして応用するた 
めには, 大きな推力で, かつ推力リプルが小さいこと が要求される。静推力 (三相)は，(21) 式に示したよ うに, 各相の発生推力とディテントカの和である。そ こで, 静推力 (三相)の推カリプルを低減するために 発生推力の高調波成分に着目し, 考察を行った。すな わち, 永久磁石幅 $W$ と永久磁石テーパ長さ $W_{t}$ が, 発生推力 $F_{u}$ の基本波および高調波成分に与える影響 について検討した。

図 7 は $W / \tau$ と $W_{t} / W$ に対する発生推力 $F_{u}$ の基本 波および高調波成分の計算值である。同図は, 図 5 に 示した FEM の計算モデルにおいて, 一次側を電気角 で 15 度おきに移動させ，（9）式により鎖交磁束を求 め, 次に (16) 式を用いて直流電流 $I_{0}=5 \mathrm{~A}$ を流した場 合の発生推力の基本波および高調波成分を算出したも のである。

図 7 ( a ) は $W / \tau\left(W_{t}=7 \mathrm{~mm}\right)$ に対する発生推力の

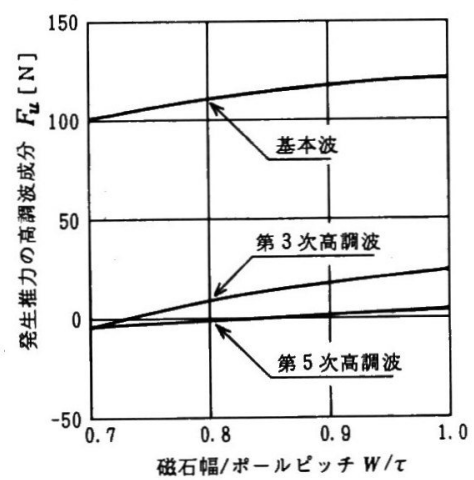

(a) $W / \tau\left(W_{t}=7 \mathrm{~mm}\right)$

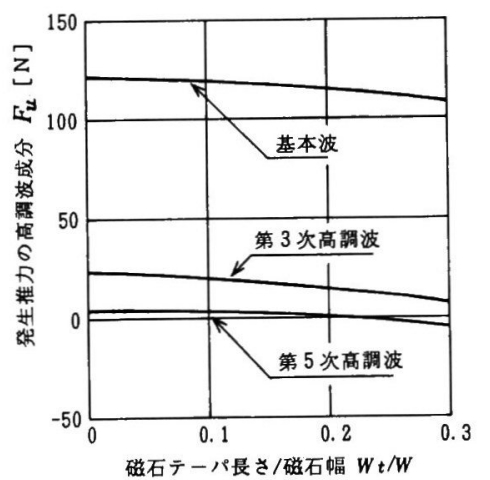

(b) $W / W(W=34 \mathrm{~mm})$

図 $7 W / \tau$ と $W_{t} / W$ に対する発生推力の 高調波成分の計算値

Fig. 7. Harmonic components of satic thrust by $W / \tau$ and $W_{t} / W$.
高調波成分である。W/ が小さくなるに従って基本 波成分および高調波成分とも隇少しており, W/ $=$ 0.73 で第三次高調波が, $W / \tau=0.84$ で第五次高調波 が零となっている。

(b) 図は $W_{t} / W(W=34 \mathrm{~mm})$ に対する発生推力の 高調波成分である。 $W_{t} / W$ が大きくなるに従って, 基 本波および高調波成分とも減少しており, $W_{t} / W=$ 0.22 で第五次高調波が零となっている。

図 7 は永久磁石形 LSM を設計するための重要な指 針を与えている。すなわち, 静推力の第三次, 五次高 調波成分を低減するためには， $W_{t}=7 \mathrm{~mm}$ の場合, $W / \tau=0.73$ 付近に設計すればよいことを示している。

\section{LSM の静推力特性}

永久磁石形 LSM を試作し, 静推力の実測值と計算 值の比較を行った。図 8 に試作機の外観を示す。一次 側 (可動子) の外形寸法は, 長さ $263 \mathrm{~mm}$, 幅 $207 \mathrm{~mm}$, 高さ $59 \mathrm{~mm}$ で, ストロークは, $1,200 \mathrm{~mm}$ である。

表 2 は試作機の二次側の諸元である。一次側の歯寸 法は表 1 に示した值で, 永久磁石の寸法は, 磁石幅 $W=34 \mathrm{~mm}$, 磁石テーパ長さ $W_{t}=7 \mathrm{~mm}(W / \tau=$ $\left.0.85, W_{t} / W=0.21\right)$ である。この永久磁石寸法は, 図 7 に示した発生推力の特性より決定した。すなわ ち, 上記の磁石寸法にすることで, 静推力の基本波を あまり減少することなく, 第三次高調波成分を軽隇で

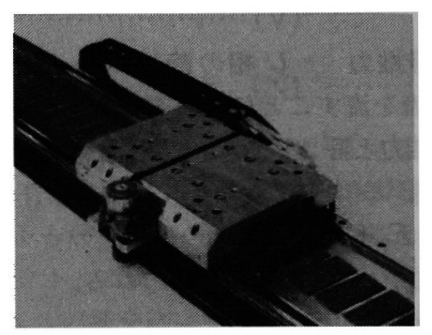

図 8 試作機の外観

Fig. 8. Appearance of the LSM.

表 2 永久磁石形LSMの試作機の諸元 Table 2. Parameters of experimental LSM.

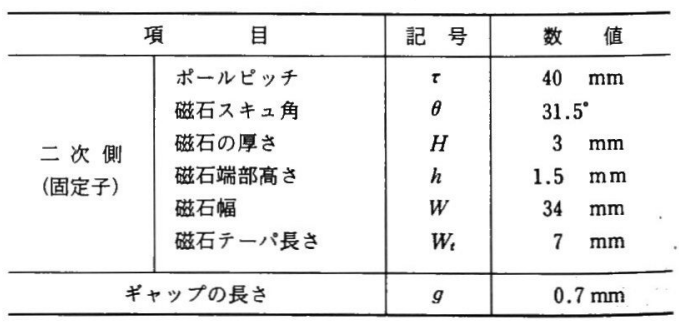


き，また第五次高調波成分をほほ褰にすることができ 万。

更に，静推力の高調波成分の低減化のために永久 磁石を 1 スロットピッチ（電気角で31.5度, 長岕て $7 \mathrm{~mm})$ スキュさせた。これは，スキュの効果によ り高摆波成分の鎖交磁束を減少させることで，静推力 の高調波成分を低隇させることをねらったものて ある。

$\langle 4 \cdot 1\rangle$ 速度起電力特性速度起電力の実測值と 計算值を比較することて，磁束の解析精度を確認 する。

一次側可動子を一定速度で移動させたときにコイル に発生する速度起電力を FFTで測定した。

図 9 は可動子の移動速度 $160 \mathrm{~mm} / \mathrm{s} に$ に㧍ける速度起 電力特性である。（a）図は相電圧および線間電圧の速 度起電力波形て，相電圧に切ける破線は FEM 解析に よる部算值 (12)式によるものて，一点鎖線はパーミア ンス法による計算值 ( 5 ) 式によるものである。また，

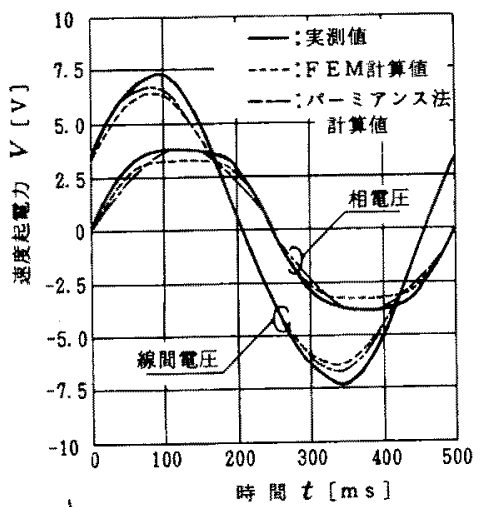

(a) 速度起電力波形

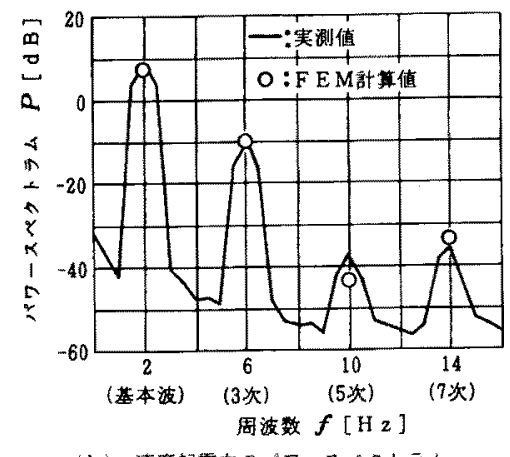

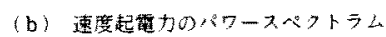

図 9 速度起電力特性

Fig. 9. Speed electromotive force characteristics.

電学論 $\mathrm{D}, 111$ 巻 6 号, 平成 3 年
線間電圧は，二つの相の相電生の和として求めた。な お計算值には，磁石をスキューしたことによる影幚は 考慮していない。

FEM 解析による計算值は，実測值の傾问をよく捕 らえており，その献差は約 10\%である。また，パー ミアンス法による相電压計算值と，実测值の波高值は ほほ一致しているが，高調波を考慮していないため， その傾向は大きく異なっている。

(b)図流相電纴の速度起電力のパワースペクトラム である。同図における FEM 部算值は，(12)式の速度 起笔力から相電王のパワースペクトラムを求めた。 FEM 計算值は，奏湘值の傾问とほほ一致しており， 磁束に関する本解析手法の妥当性を裹付けている。

〈4・2〉静推力特性 静推力 (三相) は，(21)式 に示したように, 各相の発生推力とディテント力の和 として表した。そこでまず，静推力（一相）の実測值 と計算值の比較を行う。

図 10 に静推力 (一相) の静推力特性を示す。これ は, 直流電流 $I_{0}=5 \mathrm{~A}$ を流したときの特性である。同 図に抢いて，破線はFEM解析による計算值 (18) (20)式によるもので，一点鎖線はパーミアンス法によ る計算值 (6)式で計算した。

FEM 解析による計算値は, 実測値とほほ一致し, 計算言善は $10 \%$ 程度である。また、パーミアンス法 による計算値は、ディテント力を考慮していないため 実測值と大きく琵なっている。

また，図 10 に示したディテント力 $\left(I_{0}=0 \mathrm{~A}\right)$ の最

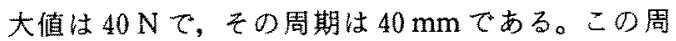
期はポールピッチと一致し，一次側端部の影響が大き く現れていることを示している。

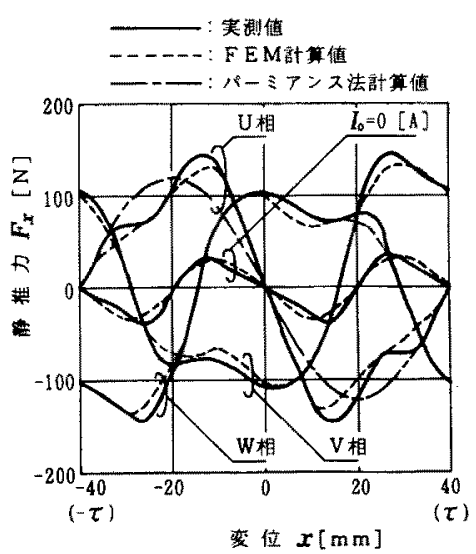

困 10 静推力(一相) の静推力特性 Fig. 10. Static thrust characteristics by the one-phase excitation. 


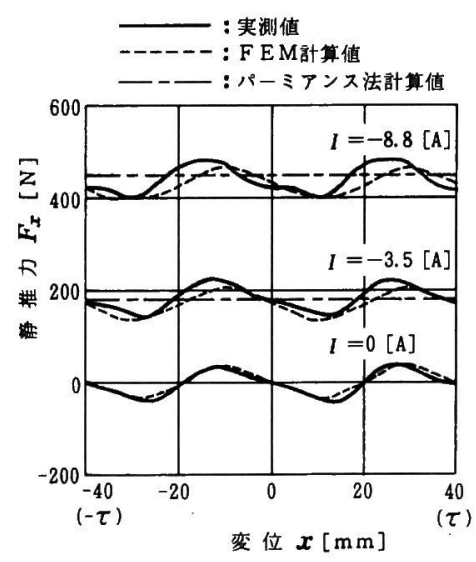

図 11 静推力（三相）の静推力特性 Fig. 11. Static thrust characteristics by the three-phase excitation.

図 11 に, 静推力(三相)の静推力特性を電流をパラ メータとして示す。同図に颃いて破線は FEM 解析に よる計算值(21)式によるもので, 一点鎖線はパーミア ンス法による計算式（７）によるものである。FEM お よびパーミアンス計算值の計算誤差は, それぞれ 10 および $20 \%$ 程度である。これらの計算誤差は, 速度 起電力および静推力（一相）の計算誤差とそれぞれ一 致する。

また, 各電流值における推力の脈動は, ほぼディテ ントカと一致しており, 各電流值における静推力から ディテントカを差引いた推力分布は，平たんな特性で あることがわかる。静推力リプル低減化のためには, ディテントカの軽減が必要である。

更に, 電流 $I=-8.8 \mathrm{~A}$ において実測值の最大值お

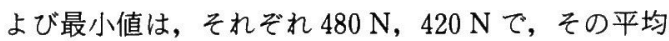

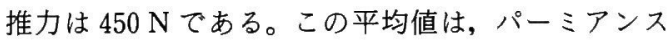
法による計算值 $453 \mathrm{~N}$ とほほ一致する。従って, パ ーミアンス法による計算値は, 平均静推力を算出して いることになる。

\section{5.あとがき}

永久磁石形 LSM の静推力の表現式をパーミアンス 法㧍よび二次元 FEM を用いて導出し，試作機によ り，その解析の妥当性を確認した。

本論文で得られた結果は, 以下のとおりである。

（1）永久磁石の磁石幅およびテーパ長さが, 静推 力の高調波成分に大きな影響を与えることを FEM 解 析により明らかにし, 静推力の高調波成分を低減する 磁石寸法（W/ $\left.=0.73, W_{t}=7 \mathrm{~mm}\right)$ を示した。
（2）上記の検討結果に基づき，最大静推力 $450 \mathrm{~N}$ $(8.8 \mathrm{~A})$ の試作機を製作し, 解析手法の妥当性を確認 した。すなわち, 速度起電力および静推力の実測值に 対する FEM およびパーミアンス法による計算誤差 は，それぞれ 10 および $20 \%$ 程度である。

（3）パーミアンス法による計算値は, 平均静推力 の実測値と一致する。パーミアンス法による静推力の 計算方法は簡便であり, 永久磁石形 LSM の概略設計 に有用であると考える。

最後に，本研究について熱心な御討論をいただいた 電気学会リニアモータ FA 応用調查専門委員会 (委員 長 武蔵工業大学 海老原助教授) の各委員に対して深 謝の意を表する。

(平成 2 年 8 月 29 日受付, 同 2 年 12 月 10 日再受付)

\section{文献}

（1）山田編著：リニアモータ応用ハンドプック, p. 2(昭 61) I 業調查会

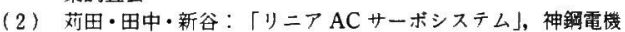
技報 118 号, 35(昭 63)

（3）金沢・宮下・山下：「搬送用 ACリニアアクチュエータの特 性改善」, 電気学会マグネティックス研資, MAG-86135(昭 61)

（4）水野・小俣：「永久磁石形 LSM の静推力解析」, 電気学会り ニアドライブ研資, LD-90-28(平 2)

（5）大川：フェライト磁石回転機の設計, p. 142 (昭 59) TDK

（6）山本監修: 電磁界解析のための有限要素法, p. 167 (昭 63) 卜 リケップス

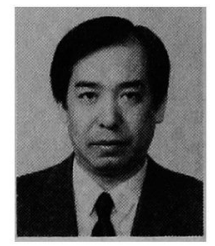

\section{水 野 魅（正員）}

昭和 33 年 6 月生。 58 年 3 月信州 大学大学院工学研究科電気工学専攻 修士課程修了。同年 4 月(株)アマダ 入社。同社技術研究所にてリニアモ 一夕の工作機械，板金機械への応用に関する研究開発 に従事。

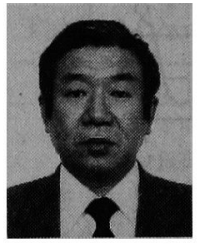

$$
\text { 山田 - (正員) }
$$

昭和 8 年 4 月生。 34 年東京工業 大学大学院修士課程修了。34 年信 州大学工学部電気工学科助手, 36 年同講師, 41 年同助教授, 59 年同 教授。工学博士。磁気回路解析を中心に据えてリニア モータ, 磁気センサと電磁形人工心臓の研究に従事。 中華人民共和国太原工業大学名誉教授。 